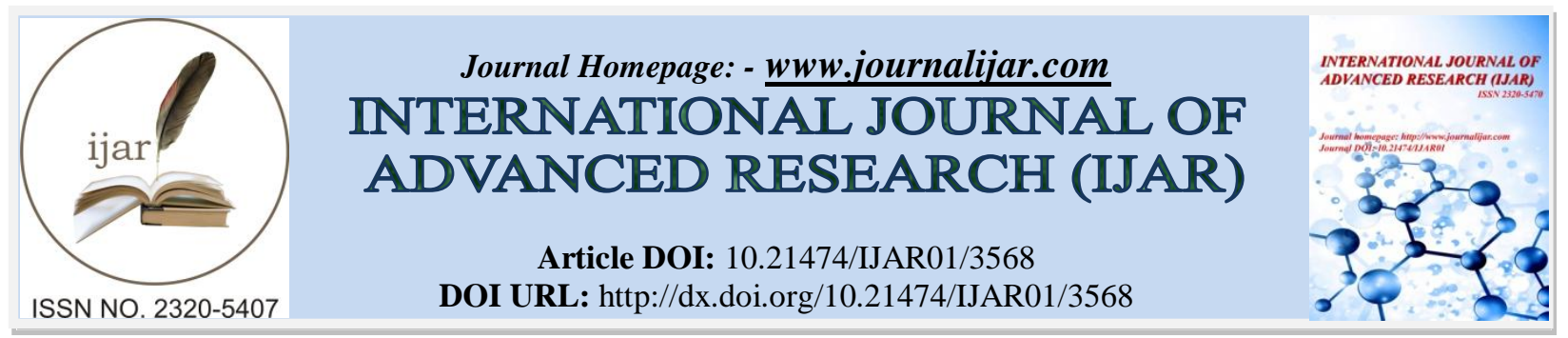

RESEARCH ARTICLE

\title{
IP-10 AS A PREDICTOR OF TREATMENT RESPONSE IN CHRONIC HEPATITIS C PATIENTS.
}

\section{Nabil Omar ${ }^{1}$, Khalid Gamil ${ }^{1}$, Mohamed Abdel-Samiee ${ }^{1}$ and Mary Naguib ${ }^{2}$.}

1. Hepato-Gastroenterology, National Liver Institute, Menoufia University, Shebin El-Kom, Menoufia, Egypt.

2. Clinical and Chemical Pathology department, National Liver Institute, Menoufia University, Shebin El-Kom, Menoufia, Egypt.

\section{Manuscript Info}

Manuscript History

Received: 03 January 2017

Final Accepted: 05 February 2017

Published: March 2017

\section{Abstract}

Background \& Aim: Hepatitis C virus (HCV) is a globally prevalent pathogen and a leading cause of death and morbidity. IFN-gamma inducible protein $10 \mathrm{kDa}$ (IP-10, or CXCL10), predict a more pronounced first phase decline of HCV RNA during anti-viral therapy. We assessed pretreatment serum IP-10 as a predictor of SVR in treated chronic HCV.

Subjects and methods: Seventy adult chronic HCV patients were included in the prospective controlled study and 10 healthy subjects as a control group. All patients were treated with combined pegylated interferon and ribavirin therapy: pegylated IFN- $\alpha 2 b, 1.5 \mu \mathrm{g} / \mathrm{kg} / \mathrm{week}$ or pegylated IFN- $\alpha 2 \mathrm{a}, 180 \mu \mathrm{g} /$ week $\mathrm{SC}$ plus ribavirin $(15 \mathrm{mg} / \mathrm{kg} /$ day orally) for 48 weeks and were followed up for 6 months later.

Results: There was statistically significant difference between the NonSVR group and SVR group as regards IP10 level $(395 \pm 167.9$ vs. $159.9 \pm 55.2) \mathrm{pg} / \mathrm{ml}$; AFP level $(7.2 \pm 11.4$ vs. $3.8 \pm 1.8) \mathrm{ng} / \mathrm{ml}$ and Liver Stiffness measurement by transient elastography $(10.9 \pm 6.3$ vs. 7.4 \pm 2.5 ) kpa, respectively. On multivariate regression analysis for predictors of post-treatment SVR: IP10 was the only independent predictor of achieving SVR (Odds=0.97; C.I 95\%= 0.95-0.99; $\mathrm{P}=0.002)$. At cutoff point for IP10 more than $216.6 \mathrm{pg} / \mathrm{ml}$ has a sensitivity of $90 \%$, specificity $87.5 \%$, PPV $84.4 \%$ and NPV $92.1 \%$ at P $=0.001 ;$ C.I $95 \%=0.900-1.000$ to define patients with SVR.

Conclusion: Pretreatment IP-10 level should be included as a predictor of SVR. Attempts to neutralize IP-10 or block IP-10 receptor should be considered as additional strategies to improve the outcome of the antiviral therapy.

Copy Right, IJAR, 2017,. All rights reserved.

\section{Introduction:-}

Hepatitis C virus (HCV) is a global health problem with $>185$ million (2.8\%) infections worldwide (Mohd et al, 2013). There is substantial regional variation where Egypt is estimated to have the highest HCV prevalence in the world (14.7\%) (Cuadros et al., 2014).

As a consequence of asymptomatic progression of chronic $\mathrm{HCV}$ infection, almost $75 \%$ of patients first present with complications of cirrhosis, portal hypertension and later develop hepatocellular carcinoma (HCC) (Mitchell et al,

Corresponding Author:- Mohamed Abdel-Samiee.

Address:- Hepato-Gastroenterology, National Liver Institute, Menoufia University, Shebin El-Kom,

Menoufia, Egypt. 
2010). Some estimations suggest that death related to HCV infection (due to liver cell failure or hepatocellular carcinoma) will increase over the next two decades (Ghany et al., 2009).

Cellular immune response induced to HCV may affect the severity of liver injury. Inflammatory responses are regulated by complex mechanisms and probably depend on genetic determinants such as HLA expression and chemokines such as interferon-gamma-inducible protein-10 (IP-10) (Hraber, 2007 and Larrubia, 2008).

The treatment regimen with pegylated interferon (PEG-IFN) alfa-2a or alfa-2b together with ribavirin (RBV) was the standard of care (SOC) for HCV patients (Alexopoulou \& Karayiannis, 2015). With improved understanding of the HCV genome, key viral enzymes and life cycle, direct-acting drugs (DAAs) have developed, that show good promise for the future (Alexopoulou \& Karayiannis, 2015).

Response to treatment is affected by various viral and host factors. Among the identified predictors of response, the host genetic polymorphisms and the pre-treatment activation of IFN-stimulated genes (ISG) (Kau et al, 2008, Fattovich et al, 2011).

Single nucleotide polymorphisms (SNPs) near IL28B, which encodes the type III interferon IFN- $\lambda 3$, can be used in routine clinical practice for informing treatment decisions. IFN- $\lambda 3$ are strongly associated with the response to treatment of chronic hepatitis $\mathrm{C}$, it up regulates IFN-stimulated genes and affects the adaptive immune response (Rauch et al, 2010; Thompson et al, 2010). However, the IL28B genotype alone is not a perfect predictor of treatment outcome (Ogawa et al., 2012).

On the other hand, it has been shown that low levels of intrahepatic and systemic chemokine CXC IFN-gamma inducible protein $10 \mathrm{kDa}$ (IP-10, or CXCL10), a valid surrogate marker of ISG activation, predict a more pronounced first phase decline of HCV RNA during anti-viral therapy (Askarieh et al, 2010) and increased SVR rates (Romero et al, 2006).

$\mathrm{HCV}$ itself is suggested to be responsible for elevated serum IP-10 levels found in HCV-infected patients. HCV proteins such as NS5A and core, alone or in combination with proinflammatory cytokines, can induce IP-10 gene expression and secretion (Apolinario et al., 2005). Pretreatment IP-10 levels correlated with HCV viral load, ALT levels, hepatic inflammation and fibrosis. Potent DAA therapy is associated with a rapid reduction in plasma IP-10 level that parallels the reduction in HCV RNA level, both in treatment-naive patients and treatment-experienced patients (Chatterjee et al., 2012).

Aim:-

The aim of this work was to assess pretreatment serum IP-10 as a predictor of SVR in treated chronic HCV Egyptian patients

\section{Subjects and Methods:-}

This prospective controlled study was conducted on 70 patients with chronic hepatitis $\mathrm{C}$ virus infection. They were recruited from the outpatient clinic of Hepato-Gastroenterology department, National Liver Institute, Menoufia University. All patients were $\geq 18$ years old, and eligible for pegylated interferon plus ribavirin therapy. Diagnosis of chronic HCV was confirmed by real-time PCR. Patients underwent antiviral treatment and follow-up protocol according to the standard clinical practice for 18 months. In addition, 10 apparently healthy subjects of matched age and gender were enrolled as a control group. The study was approved by the ethics committee, and enrollment in the study was conditioned by a written informed consent from all participants in the study.

\section{Exclusion criteria:-}

1- Previously treated, or not eligible for treatment. 2- Patients with HBV or HIV coinfection. 3- Patients with evidence of HCC or other liver diseases. 4- Patients having moderate to severe uncorrected anemia, neutropenia and thrombocytopenia. 5- Patients with a history of cardiovascular and neuro-psychiatric diseases.

All patients were treated with combined pegylated interferon and ribavirin therapy: pegylated IFN- $\alpha 2 b$ $1.5 \mu \mathrm{g} / \mathrm{kg} /$ week or pegylated IFN- $\alpha 2 \mathrm{a} 180 \mu \mathrm{g} /$ week SC per week, plus ribavirin $15 \mathrm{mg} / \mathrm{kg} /$ day orally. Patients received treatment for 48 weeks and were followed up for 6 months after the end of treatment. 
A rapid virological response (RVR) was defined as undetectable HCV RNA in serum at week 4 of therapy. Early virological response (EVR) was defined as serum HCV RNA negativity or any >2 log 10 decline in HCV RNA levels at week 12 of therapy compared with baseline. Patients with sustained virological response (SVR) were those with undetectable HCV RNA in serum 24 weeks after stopping therapy. Treatment failures included patients who had a $<2 \log 10$ drop in viral load at week 12 as compared to baseline, those whose HCV RNA was still detectable at week 24 (i.e. nonresponders), and those who had undetectable HCV RNA at the end of therapy but detectable HCV RNA at 24 weeks after cessation of therapy (i.e. relapsers) (Ghany et al., 2009).

\section{Laboratory Assessment:-}

Base line investigation; blood samples were taken before starting treatment. They were tested for: HCV RNA using the COBAS ${ }^{\circledR}$ TaqMan ${ }^{\circledR}$ HCV Quantitative Test (Roche Molecular Diagnostics, CA, USA) with lower limit of quantitation of $15 \mathrm{IU} / \mathrm{ml}$; complete blood count (CBC) using Sysmex K-21 (Sysmex Corporation, Japan); blood sugar, liver \& kidney function tests using fully automated Beckman Coulter chemistry analyzer Au 480 (Beckman Coulter Inc., CA, USA); alpha fetoprotein (AFP) \& TSH hormone using (Advia Centaur CP immunoassay system, Siemens Healthcare Diagnostics Inc, USA)

Repeated measurements of liver function tests, complete blood count and HCV RNA were done on weeks (12, 24, and 48 ) during treatment and at 6 months after stopping therapy.

\section{End Points:-}

SVR response was considered as primary end point. Non-response and/or relapse were considered as the secondary end point.

\section{Quantification of serum level of IP-10:-}

Interferon- $\gamma$ Inducible Protein -10 (IP- 10) levels were measured in serum samples (separated and stored at - 80C) using a solid phase sandwich ELISA immunoassay (Quantikine human CXCL10 / IP10 immunoassay, R\&D System, Minneapolis, USA) according to the manufacturer's instructions.

\section{Liver biopsy:-}

Ultrasound-guided percutaneous liver biopsy was performed to determine the degree of liver fibrosis at baseline. The histopathological assessment of necro-inflammatory grade and fibrosis stage was recorded using Metavir scoring system (Fibrosis was staged on a 0-4 scale. Activity was graded as: A0, none; A1, mild; A2, moderate; and A3, severe. Fibrosis stages $\geq$ F2 were considered significant) before commencing treatment (Bedossa et al., 1996).

\section{Radiological investigations:-}

All patient had abdominal ultrasonography; liver stiffness measurement (LSM) by transient Elastography using fibroscan apparatus ((Echosens, Paris, France) done initially within a week of liver biopsy and at the end of followup period (Andersen et al., 2009).

\section{Statistical analysis:-}

Data was statistically analyzed using IBM® SPSS ${ }^{\circledR}$ Statistics ${ }^{\circledR}$ version 21 for Windows. Data are expressed as mean \pm standard deviation, number with column percentage and the median \pm range or $95 \%$ confidence interval for non-parametric data. All p-values are 2 tailed, with values $<0.05$ considered statistically significant, $p=0.01$ is highly significant and $\mathrm{p}=0.001$ is very highly significant. Comparisons between two groups were performed using the Student's t-test for parametric data "normally distributed", and Mann-Whitney test for nonparametric data "not normally distributed". CHI-squared test $(\chi 2)$ and Fisher exact test for categorical data analysis. Regression analysis is used to find how one set of data relates to another. Univariate and multivariate binary logistic regression were done for detecting the predictors of the event.

The area under the receiver operating characteristic (AUROC) curve analysis was used for detection of the cutoff value of the proposed tests. An AUROC value of 0.90-1.0 indicated excellent, 0.80-0.89 good, 0.70-0.79 fair, 0.600.69 poor and 0.50-0.59 no useful performance for discrimination of the outcome under assessment. Sensitivity: the proportion of patients with disease who are correctly identified. Specificity: the proportion of patients without disease who are correctly identified. Positive predictive value: the proportion of patients with positive test results who are correctly diagnosed. Negative predictive value: the proportion of patients with negative test results who are correctly diagnosed. 


\section{Results:-}

This was a prospective randomized controlled study which was conducted on 70 chronic hepatitis $\mathrm{C}$ patients and 10 healthy persons enrolled as a control group. They were recruited from the outpatient clinic of Hepatology department, National Liver Institute, Menoufia University.

\section{Comparison between control group and treated group:-}

There was statistically significant difference between both groups regarding Albumin (4.4 \pm 0.4 vs. $4 \pm 0.2) \mathrm{g} / \mathrm{dl}$, AST (21.3 \pm 4 vs. $49.6 \pm 38.2)$ U/L, ALT $(29.9 \pm 4.2$ vs. $53.7 \pm 39.2)$ U/L, Creatinine ( $0.7 \pm 0.1$ vs. $0.8 \pm 0.2) \mathrm{mg} / \mathrm{dl}$, Platelets $(253900 \pm 56398.3$ vs. $6734.4 \pm 2165.5) / \mathrm{mm}^{3}$ and IP10 (102.2 \pm 51 vs. $\left.260.7 \pm 165.2\right) \mathrm{pg} / \mathrm{ml}$ in the control group vs. treated group respectively.

However, there was no statistical difference between both groups regarding age, TSH, RBS, AFP, bilirubin, WBCs, Hb, Prothrombin conc. And INR

The mean \pm SD of transient elastography was $(8.9 \pm 4.8) \mathrm{kpa}$ in the treated group patients before starting treatment. The base-line HCV RNA level was (1548683.5 \pm 1955482.9$) \mathrm{IU} / \mathrm{ml}$ in treated group (table 1, Figure 1)

Comparison between sustained vs. non sustained virus responders:-

Sustained virus response (SVR) comprise $57.1 \%$ of chronic hepatitis C patients as 40 patients achieved SVR while 30 patients were Non-SVR achievers, who were further subdivided to 20 non responders who did not achieve the end of treatment (EOT) and 10 relapsers (achieved EOT but not SVR).

There was statistically significant difference between the Non-SVR group and SVR group as regards IP10 level (395 \pm 167.9 vs. $159.9 \pm 55.2) \mathrm{pg} / \mathrm{ml}$ (table and figure 2$)$; AFP level $(7.2 \pm 11.4$ vs. $3.8 \pm 1.8) \mathrm{ng} / \mathrm{ml}$ and Liver Stiffness measurement by transient Elastography (10.9 \pm 6.3 vs. $7.4 \pm 2.5) \mathrm{kpa}$, respectively (table 2, figure 3). On the other hand, there was no statistically significant difference between the two groups as regarding age, bilirubin, albumin, AST, ALT, creatinine, hemoglobin, WBCs, platelets, prothrombin conc., INR and base line HCV RNA level (table 2)

However, there was a significant difference between the two groups regarding the presence of significant fibrosis ( $\mathrm{F}$ $\geq 2)(\mathrm{P}=0.009)$ (table 3$)$ and activity $(\mathrm{P}=0.023)$ by Metavir scoring (table 4$)$. Furthermore, there was a significant difference between both groups regarding the achievement of RVR (rapid viral response), EVR (early viral response) and EOT (end of treatment response). As 37 (92.5\%) RVR achievers ( $\mathrm{P}=0.023)$ (table 5, figure 4), 39 $(97.5 \%)$ EVR achievers $(\mathrm{P}=0.001)$ and $40(100 \%)$ patients who achieved EOT were SVR achievers $(\mathrm{P}=0.001)$ (table 6, figure 4).

Comparison between patients with non-significant fibrosis and patients with significant fibrosis:-

There was statistically significant difference between both groups as regarding age which was significantly higher in patients with significant fibrosis than in those with non-significant fibrosis $(47.5 \pm 7.8$ vs.39.7 \pm 10.6 years old $)$. Prothrombin conc. was significantly lower in patients with significant fibrosis $(83.7 \pm 10.2$ vs. $89.3 \pm 8.6)$ and INR was significantly higher in patients with significant fibrosis than in those with non-significant fibrosis ( $1.2 \pm 0.1$ vs. $1.1 \pm 0.1)$.

RBS and Transient Elastography were higher in patients with significant fibrosis than in those with nonsignificant fibrosis with values ( $121.6 \pm 37.7 \mathrm{vs.} 100.8 \pm 17.7 \mathrm{mg} / \mathrm{dl})$ and $(15.4 \pm 6.5 \mathrm{vs} .7 .1 \pm 1.9 \mathrm{kpa})$ respectively.

On the other hands, there was no statistical significance between two groups concerning IP10, Bilirubin, Albumin, AST, ALT, Creatinine, Hb, WBCs, Platelets, AFP, TSH and base-line HCV RNA level (table 7).

However, there was a significant difference between the two groups regarding SVR as 11 out of 15 patients (73.3\%) with significant fibrosis were Non-SVR achievers vs. 19 out of 55 patients (34.5\%) with non-significant fibrosis were Non-SVR achievers $(\mathrm{P}=0.009)$ (table8).

\section{Predictors of treatment:-}

On multivariate regression analysis for Predictors of post-treatment SVR IP10 was the only independent predictor of achieving SVR (Odds=0.97; C.I 95\%= 0.95-0.99; P=0.002) (table 10). 
At cutoff point for IP10 more than $216.6 \mathrm{pg} / \mathrm{ml}$ has a sensitivity of $90 \%$ and specificity $87.5 \%$ and PPV $84.4 \%$ and NPV $92.1 \%$ at $\mathrm{P}=0.001$; C.I 95\% $=0.900-1.000$ to define patients with SVR(figure 6).

Table 1:- Baseline characteristics of treated group vs. control group

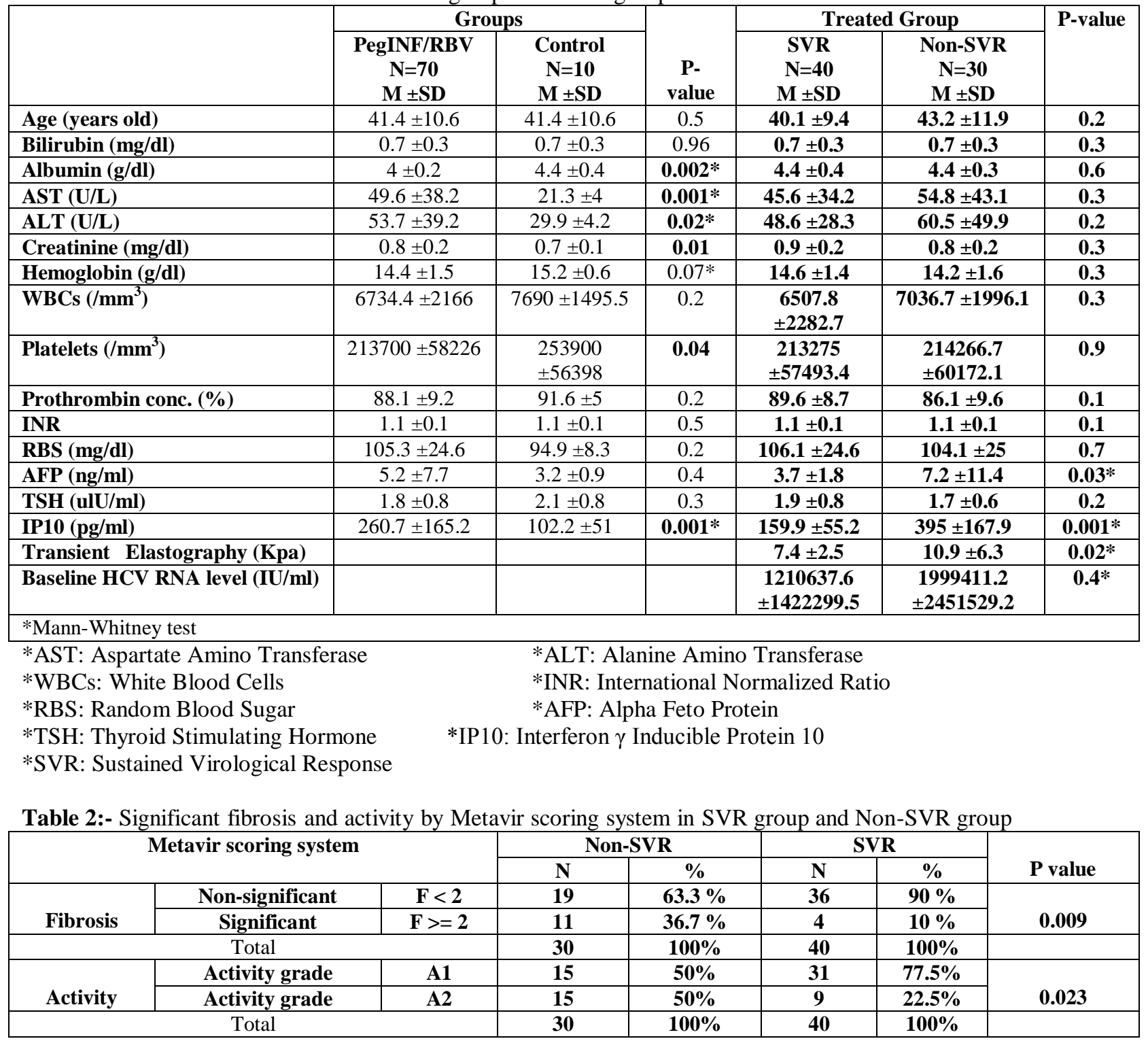

Table 3:- RVR, EVR and EOT in SVR group and Non-SVR group.

\begin{tabular}{|c|c|c|c|c|c|c|}
\hline & & \multicolumn{2}{|c|}{ Non-SVR } & \multicolumn{2}{|c|}{ SVR } & \multirow[b]{2}{*}{$P$ value } \\
\hline & & $\mathbf{N}$ & $\%$ & $\mathbf{N}$ & $\%$ & \\
\hline \multirow[t]{2}{*}{ RVR } & Non-RVR & 9 & $30 \%$ & 3 & $7.5 \%$ & \multirow[b]{2}{*}{0.023} \\
\hline & RVR & 21 & $70 \%$ & 37 & $92.5 \%$ & \\
\hline \multicolumn{2}{|c|}{ Total } & 30 & $100 \%$ & 40 & $100 \%$ & \\
\hline \multirow[t]{2}{*}{ EVR } & Non-EVR & 11 & $36.7 \%$ & 1 & $2.5 \%$ & \multirow[b]{2}{*}{0.001} \\
\hline & EVR & 19 & $63.3 \%$ & 39 & $97.5 \%$ & \\
\hline \multicolumn{2}{|c|}{ Total } & 30 & $100 \%$ & 40 & $100 \%$ & \\
\hline \multirow[t]{2}{*}{ EOT } & Non-EOT & 20 & $66.7 \%$ & $\mathbf{0}$ & $\mathbf{0 \%}$ & \multirow{3}{*}{0.001} \\
\hline & EOT & 10 & $33.3 \%$ & 40 & $100 \%$ & \\
\hline \multicolumn{2}{|c|}{ Total } & 30 & $100 \%$ & 40 & $100 \%$ & \\
\hline
\end{tabular}

*RVR: Rapid Virological Response

*EVR: Early Virological Response

*EOT: End of Treatment Response 
Table 4:- Comparison between patients with non-significant fibrosis and patients with significant fibrosis:

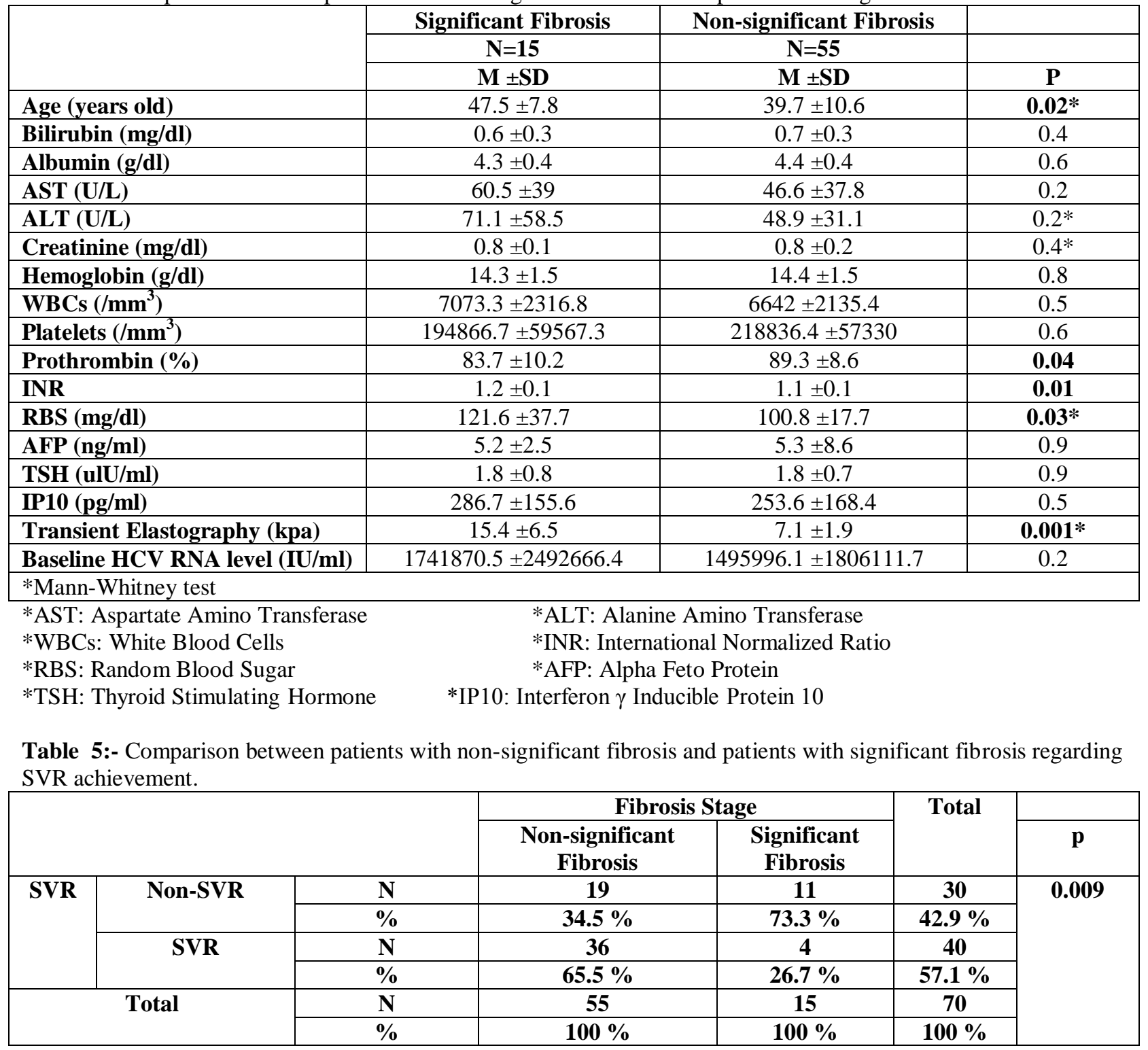

*SVR: Sustained Virological Response

There was statistically significant difference between the two groups regarding $\mathbf{S V R}$ as 11 patients (73.3\%) with significant fibrosis were Non-SVR achievers vs. 19 patients $(34.5 \%)$ with non-significant fibrosis were Non-SVR achievers $(\mathrm{P}=0.009)($ table8).

Table 6:- Multivariate regression analysis for Predictors of post-treatment SVR Predictors of SVR [multivariate analysis]

\begin{tabular}{|l|c|c|c|c|c|}
\hline & B & Wald & P & Odds & 95\% C.I \\
\hline IP10 (pg/ml) & -0.03 & 9.73 & $\mathbf{0 . 0 0 2}$ & 0.97 & $0.95-0.99$ \\
\hline Transient Elastography (kpa) & -0.26 & 1.11 & 0.291 & 0.77 & $0.47-1.25$ \\
\hline Positive RVR & -0.10 & 0.00 & 0.980 & 0.90 & $0.001-2549.78$ \\
\hline Positive EVR & -4.13 & 0.70 & 0.404 & 0.02 & $0.01-260.38$ \\
\hline Non-significant Fibrosis & 1.49 & 0.95 & 0.329 & 4.42 & $0.22-87.46$ \\
\hline Constant & 8.64 & 4.39 & 0.036 & 5667.04 & \\
\hline
\end{tabular}

*IP10: Interferon $\gamma$ Inducible Protein 10 
On multivariate regression analysis for Predictors of post-treatment SVR:-

IP10 was the only independent predictor of achieving SVR (Odds=0.97; C.I 95\%=0.95-0.99; P=0.002)(table 10).

Table 7: Receiver operating characteristic (ROC) curve analysis for IP10 to define patients with SVR:

\begin{tabular}{|c|c|c|c|}
\hline Cutoff $\geq$ & AUC & P & 95\% C.I \\
\hline $216.6 \quad 0.950$ & 0.001 & $0.900-1.000$ \\
\hline Sensitivity & & 90.0 \\
\hline Specificity & & 87.5 \\
\hline Positive predictive value & & $\mathbf{8 4 . 4}$ \\
\hline Negative predictive value & 92.1 \\
\hline
\end{tabular}

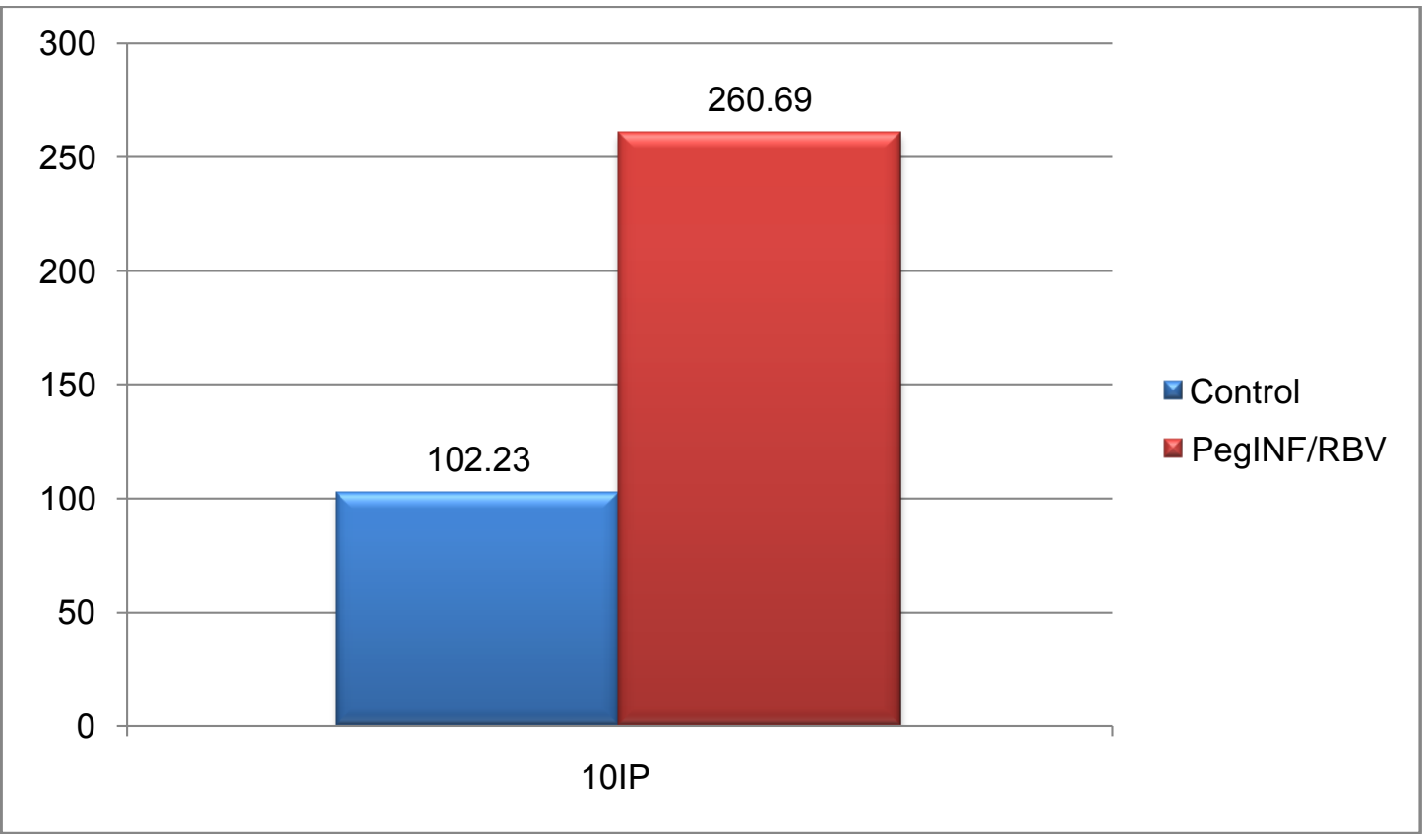

Figure 1:- IP10 level in control and treated groups

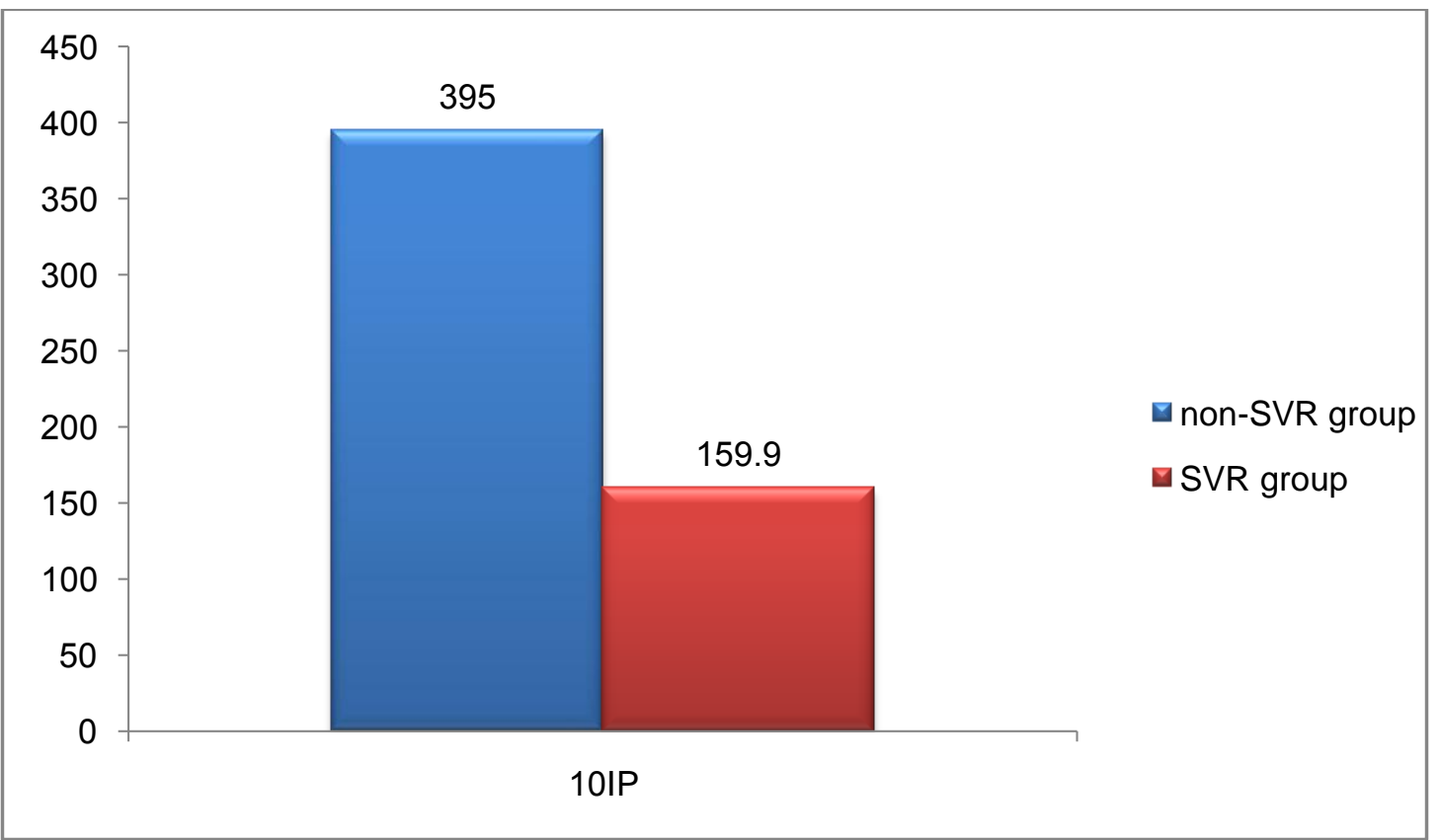


Figure 2:- IP10 level in SVR group and Non-SVR group.

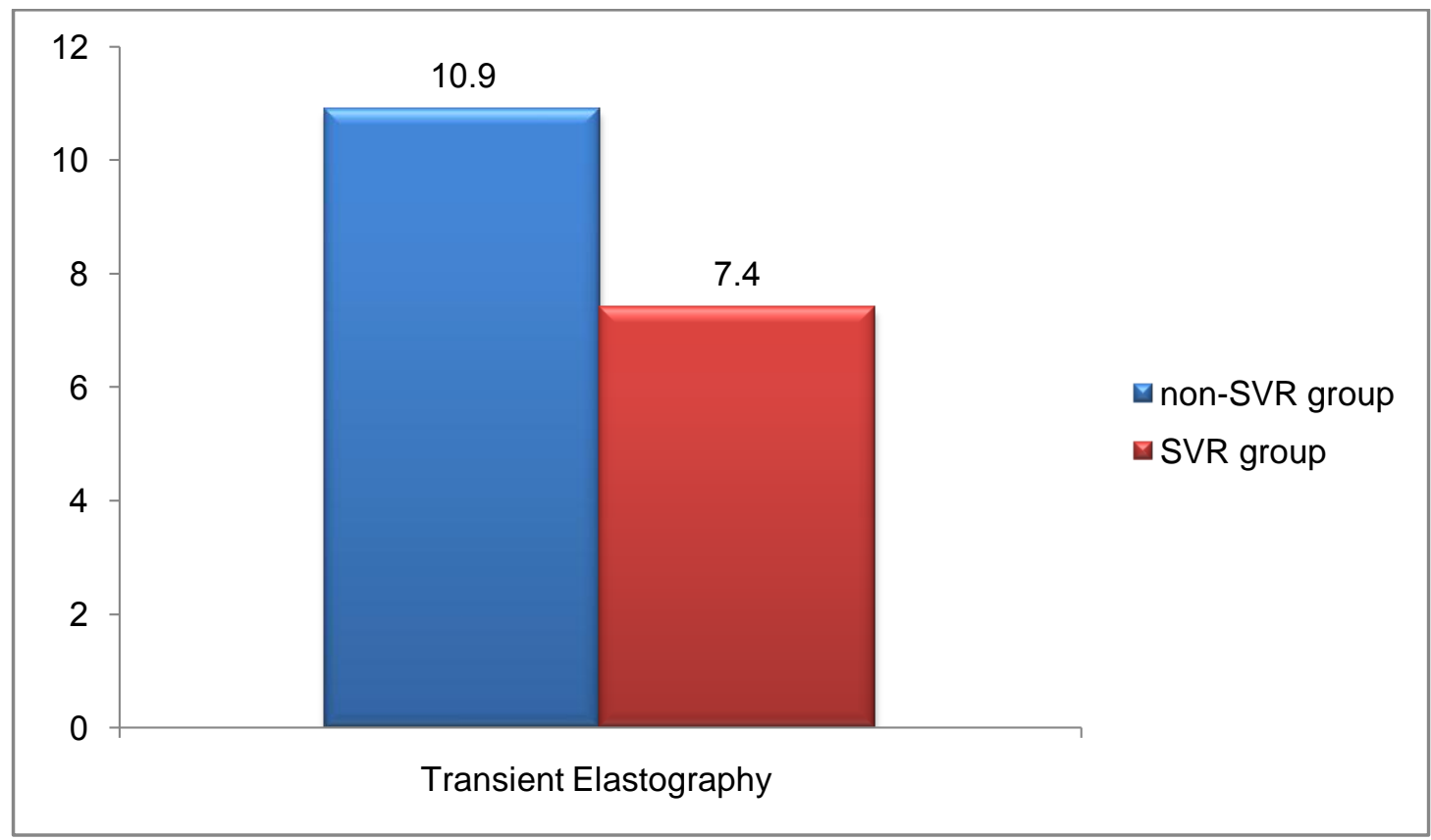

Figure 3:- Transient Elastography in SVR group and Non-SVR group.

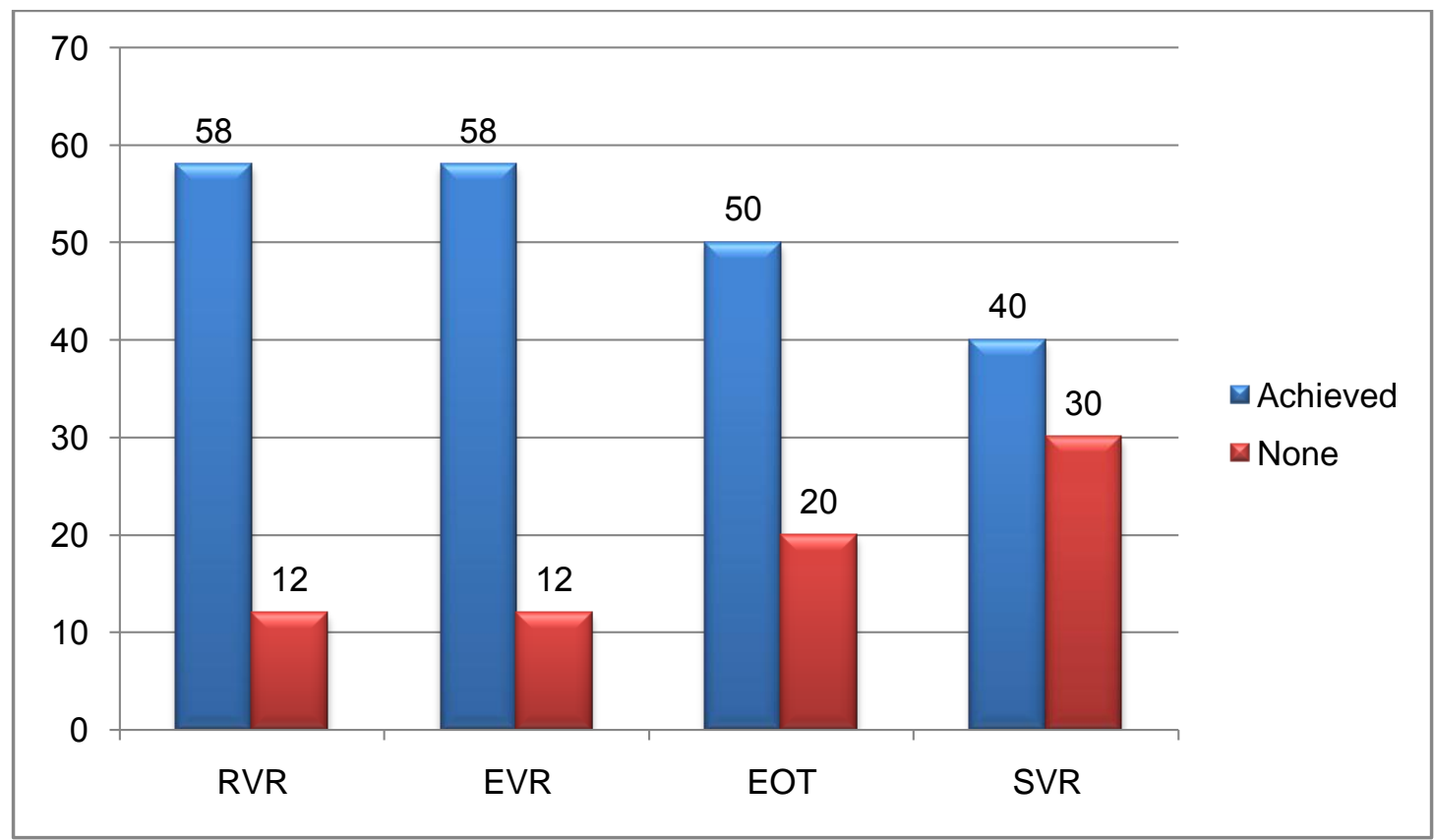

Figure 4:- Achievement of (RVR, EVR, EOT and SVR) among the studied patients. 


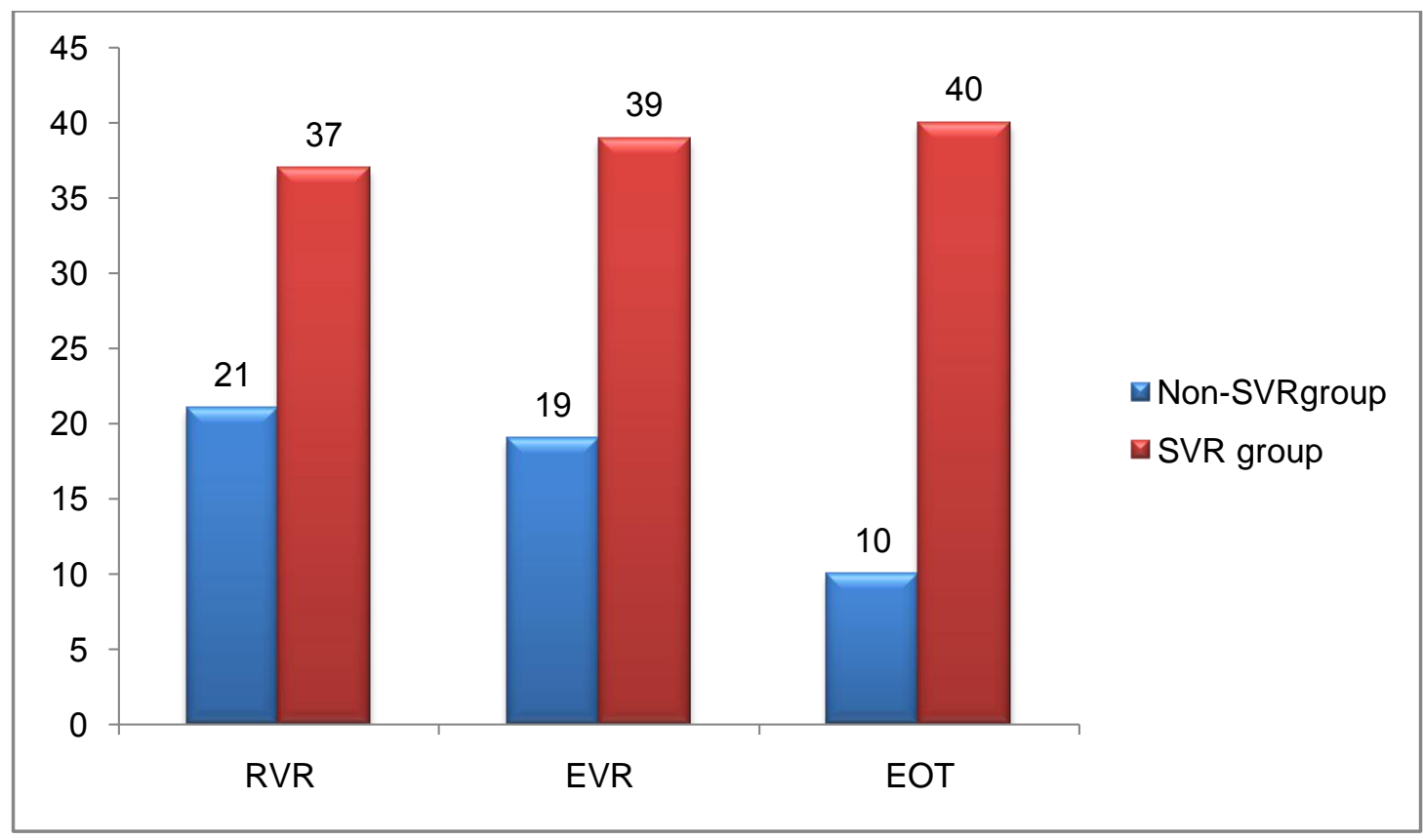

Figure 5:- Achievement of (RVR, EVR and EOT) between SVR and Non-SVR patients.

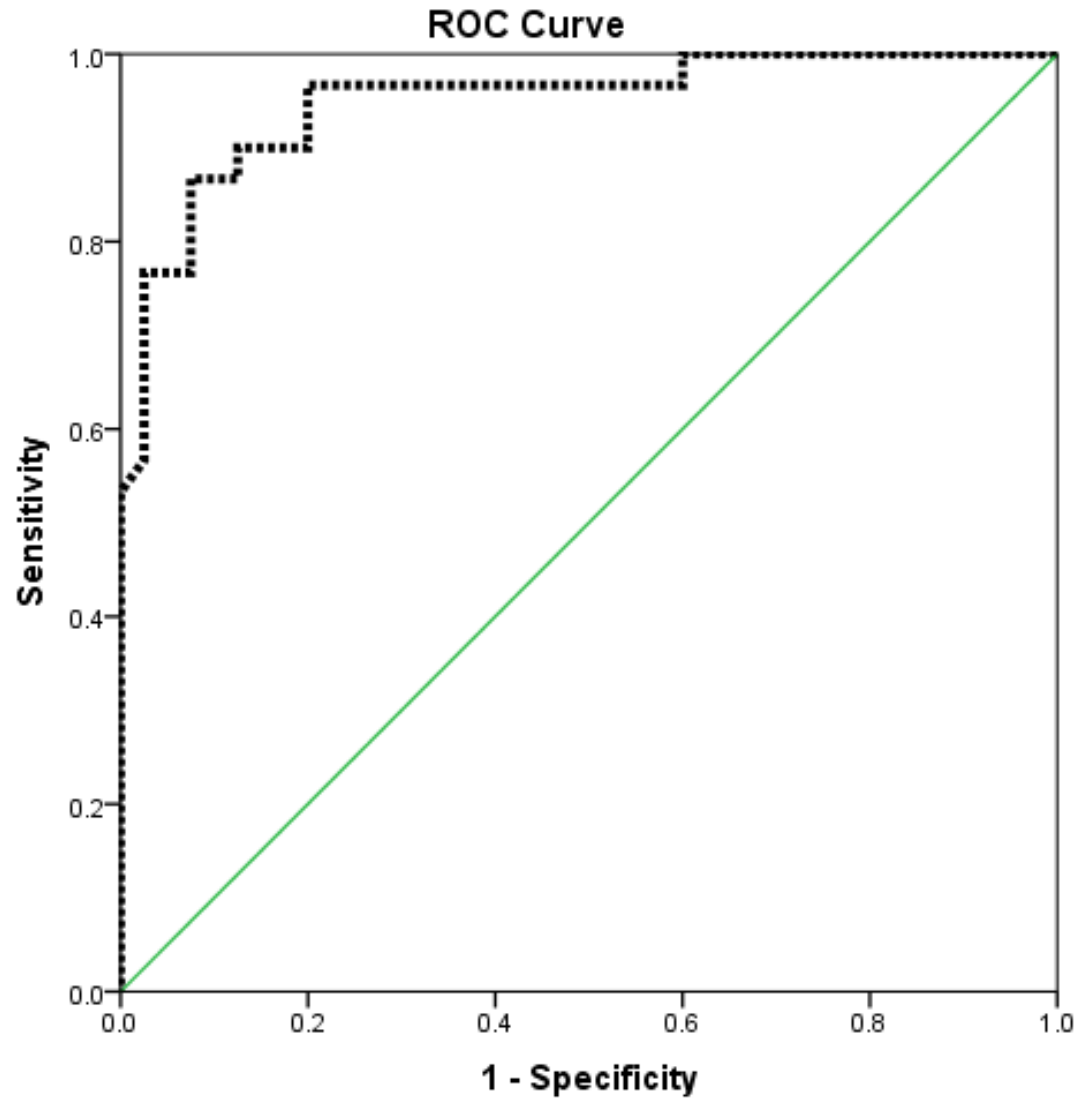

Figure 6:- Receiver operating characteristic (ROC) curve analysis for IP10 to define patients with SVR 


\section{Discussion:-}

There are many estimates of the number of people in Egypt that are infected. Many publications suggest that nearly $14 \%$ of the people in Egypt were infected. This is ten times greater than in any other country in the world (Sievert et al., 2011). The genotype 4 is predominant in $91 \%$ of these patients (Guerra et al., 2012).

The combination therapy with interferon- $\alpha$ and ribavirin, neutralize the virus after 6 months in 40-50\% of the infection cases with genotype 1 and in $80 \%$ of the infection cases with genotype 2 and 3 (Schuppan et al., 2003). Infections of $\mathrm{HCV}$ genotype 4 is, as genotype 1, relatively resistant to the interferon- $\alpha /$ ribavirin combination therapy medical treatment (El Makhzangy et al., 2009). A major paradigm shift happened in HCV treatment, with the advent of highly effective, simplified and short duration (12 weeks) oral DAA-based regimens (Dore et al., 2012). However, the effect of these new therapies, even in developed countries, will be modest without expanded access to treatment (Thomas et al., 2010).

Host genetic factors may predict the outcome and treatment response in HCV infection. IFN- $\gamma$-inducible protein 10 (IP-10; also known as CXCL-10) is a member of the CXC subfamily of chemokine. It is induced in monocytes, fibroblasts, and endothelial cells by IFN- $\gamma$. IP-10 stimulates monocytes, natural killer cell, and T-cell migration and acts as a chemoattractant for CXCR3 + T cells. Baseline plasma IP-10 levels reflect intrahepatic levels and are a prognostic marker of treatment outcome for patients treated with pegylated interferon and ribavirin (Askarieh et al., 2010).

IP-10 decrease to baseline in those who spontaneously clear infection but remain elevated in those who develop chronic infection suggesting that HCV infection itself is driving the elevated IP-10 levels (Chattergoonn et al., 2011).

The aim of this study was to assess the efficacy of serum IP-10 as a predictor of SVR in chronic hepatitis C virus Egyptian patients receiving Peg-IFN and RBV therapy. This was a prospective study which was conducted on 70 patients with chronic hepatitis $\mathrm{C}$. In addition, 10 healthy persons with matched age and sex were enrolled as a control group.

Patients were categorized into two groups according to their sustained virological response (SVR). Group (1): patients who achieved SVR. Group (2): patients who didn't achieve SVR including non-responders and relapsers.

SVR was achieved in 40 patients $(57.1 \%)$ while 30 patients were Non-SVR achievers (42.9\%); 20 of them were non-responders and 10 were relapsers. These results coincide with Gad et al. (2008) who reported that SVR rate was $54.8 \%$ in genotype-4. Another study conducted on 88 Egyptian patients with chronic HCV infection naive to treatment with PEGIFN/RBV reported SVR rate of 39.8\% (El Razikyet al., 2015).

As regards age and gender distribution we revealed that no statistically significant difference was found between SVR and Non-SVR groups ( $\mathrm{p}=0.2,0.13$ respectively). Previous studies showed that younger age of patients was a significant predictor of treatment response (Codes et al., 2007; Antonucci et al., 2007; Assad et al., 2014). However, the significance of age has not been observed concordantly with other reports. Shiffman et al. (2007) showed that older age, was not an unfavorable marker for IFN $\alpha$ treatment. In addition, Adnan et al. (2013) reported a non-significant relationship between age and response to IFN therapy. This discrepancy may come from weak power of significance and/or differences in sample size.

Several reports (Codes et al., 2007; Assad et al., 2014) showed that female sex was a significant predictor of treatment response. In addition, Di Marco et al. (2013) reported that menopause is related to an increased severity of liver fibrosis, and a lower likelihood of response to therapy with peg-IFN and ribavirin.

The decreased rate of a complete response to IFN $\alpha$ treatment may correspond to decrease in estrogen levels. Interleukin 1, associated with an inflammatory response, is stimulated by low concentrations of estrogen and progesterone. A low concentration of estrogen allows peripheral blood monocytes to secrete more interleukin 1. The spontaneous production of interleukin 1 by peripheral mononuclear cells has been shown to be significantly higher in patients with $\mathrm{CHC}$ than in healthy control individuals, and decreased in those with a complete response after the administration of IFN $\alpha$. This cytokine production may alter the effectiveness of IFN $\alpha$ treatment in perimenopausal and menopausal women with CHC infection (Di Marco et al., 2013). 
It is well known that advanced fibrosis or cirrhosis is a poor prognostic factor for response to antiviral therapy compared with no or minimal fibrosis (Poyfriedard et al., 2000; Poynard et al., 2002; Fried et al.,2002; Hadziyanniset al.,2004; Everson et al., 2006). In agreement with these studies; we found that SVR was significantly higher in patients with non-significant fibrosis than in patients with significant fibrosis as (73.3\% vs. $34.5 \% ; \mathrm{P}=0.009)$.

In addition, we found that the mean of Transient Elastography was significantly higher in Non-SVR achievers (10.9 $\pm 6.3) \mathrm{KPa}$ than in the SVR achievers $(7.4 \pm 2.5) \mathrm{Kpa}$. This was matched with Stasi et al. (2015) who showed that liver stiffness (LS) $>12 \mathrm{Kpa}$ prior to the initiation of dual therapy was significantly associated with poor response to therapy ( $\mathrm{p}<0.025$ ). LS >12 Kpa should be considered a strong prognostic indicator of non-response to anti HCV treatment (Martinez et al., 2012).

In our work, we found that RVR was a significant predictor of SVR. Thirty seven patients (92.5\%) of fourty SVR achievers were RVR while twenty one patients $(70 \%)$ of thirty Non-SVR achievers were RVR $(P=0.023)$. This was coincided with a study conducted by Ferenci et al. (2004), he observed that patients infected with HCV genotypes 2 or 3 achieved RVR in higher proportions than patients infected with genotype 1. However, regardless of the HCV genotype, patients who reached RVR have the highest rates of SVR. In the study by (Fried et al., 2011) RVR was achieved by $16 \%$ of patients with genotype $1,71 \%$ of genotype 2 and $60 \%$ of genotype 3 . Among individuals who reached RVR, the SVR rate was high across all HCV-genotypes and ranged from $88 \%$ to $100 \%$ (genotypes 1-4) (Mangia et al., 2010).

Also in our study, we found that there was statistically significant difference between SVR achievers and NonSVR achievers as regarding achievement of EVR as 39 (97.5\%) patients who achieved EVR were SVR achievers $(P=0.001)$. This was matched with a study from China which showed that patients without EVR rarely achieve SVR (Reddy et al., 2005).

In our work we found that, AFP level, was higher in Non-SVR achievers than in SVR achievers $(7.2 \pm 11.4$ vs. 3.8 $\pm 1.8 ; \mathrm{p}=.03$ ). This was matched with Males and colleagues in 2007 who confirmed the predictive role of AFP concerning treatment response to chronic hepatitis C. In a previous study, serum AFP remained independently associated with SVR after controlling other factors associated with SVR, including liver fibrosis (Dabeva et al., 1993).

Previous studies have shown that AFP can be considered as one of the serological predictors of response to antiviral therapy (Abdoul et al., 2008) as SVR to Peg-INF $\alpha /$ RBV was associated with a decrease in serum AFP (Kasztelanet al., 2003).

In our study, IP10 level was $260.7 \pm 165.2 \mathrm{pg} / \mathrm{ml}$ in the treated group. High serum IP-10 levels were associated with a failure to achieve SVR. IP-10 levels were significantly lower in patients who achieved SVR pg/ml than in NonSVR achievers ( $159.9 \pm 55.2$ vs. $395 \pm 167.9 \mathrm{pg} / \mathrm{ml} ; \mathrm{p}=0.001)$. While there was no statistically significant difference between patients with significant and non-significant fibrosis regarding IP $-10(\mathrm{P}=0.5)$. This was matched with a study done in Cairo University, Egypt which included 80 treatment naive HCV patients. Pretreatment serum IP-10 levels were significantly lower in patients who achieved SVR than in non-responders and they concluded that low pretreatment serum IP-10 is a favorable predictor of response to antiviral HCV therapy in Egyptian patients (Omran et al., 2014).

Also our results were matched with another study done on 104 Japanese, genotype 1 CHC individuals treated with PEG-IFN/RBV and 45 treated with PEG-IFN/RBV/telaprevir, and evaluated the impact of pretreatment serum IP10 concentrations on their virological responses. They concluded that pretreatment serum IP-10 concentrations are associated with treatment efficacy in PEG-IFN/RBV and with early viral kinetics of HCV in PEGIFN/RBV/telaprevir therapy (Matsuura et al., 2014).

Diago et al. (2006) reported the association of serum IP-10 levels with SVR to (PEG-IFN/RBV) therapy in patients with genotype 1 chronic HCV. They showed that the levels of IP-10 were lower in SVR patients. Noteworthy, after successful antiviral therapy, serum IP-10 concentrations decreased to levels lower than baseline, whereas they were unchanged in non-responders, suggesting that HCV itself may be responsible for elevated serum IP-10 
concentrations found in $\mathrm{HCV}$-infected patients, and thus, pretreatment serum IP-10 is an independent predictive factor of SVR in HCV patients infected by genotype 1.

On contrary; El Razikyet al (2015) found that the pretreatment serum IP-10 levels were not significantly different in relation to different grades of necro-inflammatory activity and fibrosis stages. Verifying the predictive value of pretreatment serum IP-10 levels, their study did not find a significant relation to response at week 12, 24, 48, and 72. Concentrations lower than $594.1 \mathrm{pg} / \mathrm{mL}$ had a positive predictive value of $86.8 \%$ in their study population. Also, Reiberger et al in $\mathbf{2 0 0 8}$ did not find a clear association between IP-10 levels before or during treatment and SVR. Also, Yoneda et al in $\mathbf{2 0 1 1}$ did not confirm the association between a low baseline IP-10 level and SVR. Other reports confirmed these findings; no difference was seen in baseline IP-10 levels between CHC patients with or without RVR (Falconer et al., 2010) or with or without SVR (Wan et al., 2009).

In our study, we found that a cutoff point for IP10 more than 216.6 had a sensitivity of $90 \%$ and specificity $87.5 \%$ and PPV 84.4\% and NPV 92.1\% ( $\mathrm{P}=0.001$; C.I 95\%=0.900-1.000).

IP-10 has a chemotactic function on different cell types following binding to its receptor .IP-10 recruits $\mathrm{T}$ lymphocyte subsets expressing the CXCR3 receptor, including activated $\mathrm{T}$ lymphocytes of the T helper type 1 phenotype. Also ,cytotoxic T cells and NK cells express CXCR3 and are targeted by the IP-10 chemotactic effect (Zeremski et al., 2008).

IP-10 is upregulated in the liver cells infected by HCV since strong IP-10 staining was found in the cytoplasm of the hepatocytes but not in other liver cells. It has been suggested that HCV itself may be responsible for elevated serum IP-10 levels found in HCV infected patients. HCV proteins such as NS5A and core, alone or in combination with pro-inflammatory cytokines, can induce IP-10 gene expression and secretion in human hepatocyte derived cells, leading to the accumulation of CXCR3 expressing T lymphocytes in the liver. IP-10 expression may also provide important retention signals, resulting in the observed accumulation of $\mathrm{T}$ lymphocytes (Apolinario et al., 2005).

Thus, the mechanism by which IP-10 induces treatment failure may be explained by its role in the recruitment of effector Th1 lymphocytes into the liver cells of chronic HCV patients and its potential in contributing to the host immune response against the virus as well as to the disease progression. Also, IP-10 modulates the efficacy of IFN- $\alpha$ plus ribavirin therapy by enhancing the expression of the HCV NS5A protein which induces IL-8 (CXC chemokine) secretion. IL- 8 was also found to be associated with the inhibition of the antiviral effects of IFN- $\alpha$ (Zeremski et al., 2008).

We can assume that HCV and IP-10 have synergistic effects towards each other; HCV induces IP-10 secretion by the hepatocytes, and IP-10 stimulates viral replication and inhibits the antiviral effects of IFN- $\alpha$ (Apolinario et al., 2005).

It was found that circulating CXCL10 is indeed processed into the shorter form and turns it into a CXCR3 antagonist. It was demonstrated that the short, antagonist form of CXCL10 predominates in the plasma of chronically infected patients who are destined to fail anti-HCV therapy and thus is responsible for the lack of desired antiviral effects of IP- 10 and could play an important role in pathology (Casrouge et al, 2011).

Thus, IP-10 is a strong negative predictor of response to Peg-IFN/Ribavirin therapy in HCV-4 mono-infected patients. This highlights the need to consider this factor in the individualization of treatment, and augments the level of predictiveness of IL28B polymorphisms for final treatment outcome (Charles and Dustin, 2011). As IP-10 may play a role in the mechanism of failure of antiviral therapy, interventions neutralizing endogenous IP-10 or blocking the function of its receptor, CXCR3, may provide new strategies to improve the treatment outcome of these difficultto-cure patients (Charles and Dustin, 2011).

Our study has limitations as it was conducted on a small number of patients and this population contained small percentage of patients with significant viremia and significant fibrosis. Data may not be generalizable to other study populations. Also, we did not analyze the IL-28 B polymorphism in our cohort which may interact with our results.

In conclusion, we found a strong association between low pretreatment IP-10 levels and SVR in HCV infected Egyptian patients. Pretreatment serum IP-10 level should be included as one of the predictor of response to therapy. 
Attempts to neutralize IP-10 or block IP-10 receptor should be considered as additional strategies to further improve the outcome of the antiviral therapy.

Further studies with larger samples are needed to determine the association of IP-10 and HCV treatment response especially with DAA therapy.

\section{References:-}

1. Abdoul H, Mallet V, Pol S, Fontanet A (2008): Serum alpha-fetoprotein predicts treatment outcome in chronic hepatitis C patients regardless of HCV genotype. PLoS One; 3: e2391.

2. Andersen E, Christensen P and Weis N ( 2009): Transient elastography for liver fibrosis diagnosis. Euro J Intern Med; 20 (4): 339- 342.

3. Alexopoulou \& Karayiannis (2015): Interferon-based combination treatment for chronic hepatitis $\mathrm{C}$ in the era of direct acting antivirals. Ann. Gastroenterol.; 28 (1):55-65.

4. Adnan U, Mirza T, Aziz S, Naz E (2013): Histomorphological changes in hepatitis C non-responders with respect to viral genotypes. J Pak Med Assoc; $63: 448-453$.

5. Antonucci G, Longo MA, Angeletti C, Vairo F, Oliva A, et al. (2007): The effect of age on response to therapy with peginterferon alpha plus ribavirin in a cohort of patients with chronic HCV Hepatitis including subjects older than 65 yr. Am J Gastroenterol 102: 1383-1391.

6. Apolinario A, Majano PL, Lorente R, , Núñez O, Clemente G ,García-Monzón C (2005). Gene expression profile of $\mathrm{T}$ cell specific chemokines in human hepatocyte-derived cells: Evidence for a synergistic inducer effect of cytokines and hepatitis C virus proteins. J Viral Hepat; 12: 27-37.

7. Askarieh G, Alsio A, Pugnale P, Negro F, Ferrari C, et al. (2010) Systemic and intrahepatic interferon-gammainducible protein $10 \mathrm{kDa}$ predicts the first-phase decline in hepatitis C virus RNA and overall viral response to therapy in chronic hepatitis C. Hepatology 51: 1523-1530.

8. Assad NY, Ehsan NA, Abdou AG, El-Tahmody MA, El-Sabaawy MM, El-Naidany NF, El-Kholy SS (2014): The impact of clinicopathological parameters in predicting response to pegylated interferon and ribavirin in chronic hepatitis C patients. Menoufia Med J; 27:785-92.

9. Asselah T, Marcellin P (2013): Interferon free therapy with direct acting antivirals for HCV. Liver Int 33: 93104.

10. Bedossa $\mathrm{P}$ and Poynard $\mathrm{T}$ (1996): An algorithm for the grading of activity in chronic hepatitis C. The METAVIR Cooperative Study Group. Hepatology; 24(2): 289-93.

11. Casrouge A, et al (2011). Evidence for an antagonist form of the chemokine CXCL10 in patients chronically infected with HCV. J Clin Invest.;121(1):308-317

12. Codes et al, (2007): Liver fibrosis in women with chronic hepatitis C: evidence for the negative role of the menopause and steatosis and the potential benefit of hormone replacement therapy. Gut. ; 56:390-395.

13. Cuadros DF, Branscum AJ, Miller FD, et al (2014): Spatial epidemiology of hepatitis C virus infection in Egypt: Analyses and implications, Hepatology; 51:1122-1126.

14. Charles, E.D., Dustin, L.B. (2011): Chemokine antagonism in chronic hepatitis C virus infection. J. Clin. Invest. $121,25-27$.

15. Chattergoon MA, Levine JS, Latanich R, Osburn WO, Thomas DL, Cox AL. (2011): High plasma interleukin18 levels mark the acute phase of hepatitisC virus infection. J. Infect. Dis.; 204:1730-40.

16. Dabeva MD and Shafritz DA (1993): Activation, proliferation, and differentiation of progenitor cells into hepatocytes in the D-galactosamine model of liver regeneration. Am J Pathol.; 143:1606-20.

17. Di Marco, L. Covolo, V. Calvaruso, M. Levrero, M. Puoti, F. Suter, et al (2013): Who is more likely to respond to dual treatment with pegylated-interferon and ribavirin for chronic hepatitis $\mathrm{C}$ ? A gender-oriented analysisJ Viral Hepat, 20 pp. 790-800.

18. Diago M, Castellano G, Garcia-Samaniego J, Perez C, Fer-nandez I, Romero M, Iacono OL, Garcia-Monzon C. (2006): Association of pretreatment serum interferon gamma induc-ible protein 10 levels with sustained virological response topeginterferon plus ribavirin therapy in genotype 1 infectedpatients with chronic hepatitis C. Gut 55:374-379.

19. Dore, G. J. (2012) :The changing therapeutic landscape for hepatitis C. Med. J. Aust. 196, 629-632.

20. European Association for the study of the Liver consensus panel (2012): European Association for the study of Liver International consensus conference on hepatitis C. J Hepatol.; 30:956-61.

21. El Makhzangy H, Esmat G, Said M, Elraziky M, Shouman S, Refai R, Rekacewicz C, Gad RR, Vignier N, Abdel-Hamid M,Zalata K, Bedossa P, Pol S, Fontanet A, Mohamed MK. (2009): Response to pegylated interferon alfa-2a and ribavirin in chronic hepatitis C genotype 4. J Med Virol 81(9):1576-1583. 
22. El Raziky M et al, (2015): IP 10 Serum Level in Chronic Hepatitis C Virus Patients:Relation to Fibrosis and Response to Combined Interferon/Ribavirin Therapy Journal of interferon and cytokine research Aug, 35(8):649.

23. Everson G.T., Hoefs J.C., Seeff L.B., Bonkovsky H.L., Naishadham D., Shiffman M.L. et al. (2006): Impact of disease severity on outcome of antiviral therapy for chronic hepatitis $\mathrm{C}$ : lessons from the HALT-C trial. Hepatology; 44:1675-1684.

24. Falconer K, Askarieh G, Weis N, Hellstrand K, Alaeus A, Lagging M. (2010): IP10 predicts the first phase decline of HCV RNA and overall viral response to therapy in patients co-infected with chronic hepatitis $\mathrm{C}$ virus infection and HIV. Scand J Infect Dis.; 42:896-901.

25. Fattovich G, Covolo L, Bibert S, Askarieh G, Lagging M, et al. (2011): IL28B polymorphisms, IP-10 and viral load predict virological response to therapy in chronic Hepatitis C. Aliment Pharmacol Ther 33: 1162-1172.

26. Ferenci P (2004): Predicting the therapeutic response in patients with chronic hepatitis C: the role of viral kinetic studies. J Antimicrob Chemother.; 53: 15-18.

27. Fried MW (2002): Side effects of therapy of hepatitis C and their management. Hepatology; 36: S237-44.

28. Gad, R.R., Males, S., El Makhzangy, H., Shouman, S., Hasan, A., Attala, M. et al. (2008): Predictors of a sustained virological response in patients with genotype 4 chronic hepatitis C. Liver Int.; 28: 1112-1119.

29. Ghany MG, Strader DB, Thomas DL et al. (2009): Diagnosis, Management and treatment of hepatitis C: An Update. Hepatology; 49:1335-74.

30. Guerra J, Garenne M, Mohamed MK, Fontanet A. (2012): HCV burden of infection in Egypt: results from a nationwide survey. J Viral Hepat 19(8):560-567.

31. Hadziyannis SJ, Sette H Jr, Morgan TR et al. (2004): Peginterferon-alpha2a and ribavirin combination therapy in chronic hepatitis $\mathrm{C}$ : a randomized study of treatment duration and ribavirin dose. Ann. Intern. Med.; 140: 346-55.

32. Hraber P, Kuiken C, Yusim K. (2007): Evidence for human leukocyte antigen heterozygote advantage against hepatitis $\mathrm{C}$ virus infection. Hepatology; 46:1713-1721.

33. Kasztelan-Szczerbiñska B, S³omka M, Celiñski K, Szczerbiñski M (2003): Impact of interferon-alpha therapy on the serum level of alpha-fetoprotein in patients with chronic viral hepatitis. Rocz Akad Med Bialymst; 48:74-77.

34. Kau A, Vermehren J, Sarrazin C. (2008): Treatment predictors of a sustained virologic response in hepatitis B and C. J. Hepatol.; 49(4), 634-651.

35. Larrubia JR, Benito-Martinez S, Calvino M, et al. (2008): Role of chemokines and their receptors in viral persistence and liver damage during chronic hepatitis C virus infection. World J Gastroenterol.; 14(47):7149-59.

36. Males et al (2007): Serum alpha foetoprotein level predicts treatment outcome in chronic hepatitis C. Antiviral Therapy; 12:797-803.

37. Martinez et al (2012): Longitudinal liver stiffness assessment in patients with chronic hepatitis $\mathrm{C}$ undergoing antiviral therapy. PLoS One; 7 e47715

38. Mangia A, Thompson AJ, Santoro R, Piazzolla V, Tillmann HL, et al. (2010): An IL28B polymorphism determines treatment response of hepatitis $\mathrm{C}$ virus genotype 2 or 3 patients who do not achieve a rapid virologic response. Gastroenterology 139: 821-827, 827 e821.

39. Matsuura K., et al (2014): Serum interferon-gamma-inducible protein-10 concentrations and IL28B genotype associated with responses to pegylated interferon plus ribavirin with and without telaprevir for chronic hepatitis C. Hepatol Res; 44(12):1208-1216.

40. Mitchell, et al, (2010) recommendations for the prevention and control of hepatitis B and C. Hepatology; 51(3), 729-733.

41. Mohd, et al (2013): Global epidemiology of hepatitis C virus infection: new estimates of age-specific antibody to HCV seroprevalence. Hepatology.; 57:1333-1342.

42. Moreno C, Hezode C, Marcellin P, et al. (2015): Efficacy and safety of simeprevir with PegIFN/ribavirin in naïve or experienced patients infected with chronic HCV genotype 4. J Hepatol.;62:1047-55

43. Ogawa E,Furusyo N,Murata M, et al. (2012): insulin resistance undermines the advantages of IL28B Polymorphism in the pegylated interferon alpha $-2 \mathrm{~b}$ and ribavirin treatment of chronic hepatitis Cpatients with genotype 1Journal of hepatology;57:534-540.

44. Omran D1, Hamdy S, Tawfik S, Esmat S, Saleh DA, Zayed RA (2014): Association of interferon- $\gamma$ inducible protein-10 pretreatment level and sustained virological response in HCV-positive Egyptian patients .Ann Clin Lab Sci. Spring; 44(2):167-72. 
45. Poynard T, McHutchison J., Goodman Z., Ling M.H., Albrecht J. (2000): Is an 'a la carte' combination interferon alfa- $2 \mathrm{~b}$ plus ribavirin regimen possible for the first line treatment in patients with chronic hepatitis $\mathrm{C}$ ? The ALGOVIRC Project Group. Hepatology; 31:211-218.

46. Poynard T., McHutchison J., Manns M., et al. (2002): Impact of pegylated interferon alfa-2b and ribavirin on liver fibrosis in patients with chronic hepatitis C. Gastroenterology; 122:1303-13.

47. Rauch A, Kutalik Z,Descombes P, et al. (2010). Genetic variation inIL28B is associated with chronic hepatitis C and treatment failure: a genome-wide association study. Gastroenterology; 138: 1338-45.

48. Reddy K, Rakela J, Lopez-Talavera J et al. (2005): Correlations between rapid virological response, early virological response and sustained virological response in HCV genotype 1 patients treated with pegylated interferon alfa-2a and ribavirin. Abstract S1540. Digestive Disease Week, May 14-18. Chicago, IL.

49. Reiberger T, Aberle JH, Kundi M, Kohrgruber N, Rieger A,Gangl A, Holzmann H, Peck-Radosavljevic M. (2008): IP-10 correlates with hepatitis C viral load, hepatic inflammation andfibrosis and predicts hepatitis C virus relapse or non-responsein HIV-HCV coinfection. Antivir Ther.; 13(8):969-976.

50. Romero AI, Lagging M,Westin J, et al.(2006): Interferon (IFN)-gamma inducible protein-10: association with histological results, viral kinetics, and outcome during treatment with pegylated IFN-alpha 2a and ribavirin for chronic hepatitis C virus infection. J Infect Dis; 194: 895-903.

51. Schuppan, D.; Krebs, A.; Bauer, M.; Hahn, E. G. (2003): Hepatitis C and liver fibrosis, Cell Death Differ, 10, S59-S67.

52. Sievert W, Altraif I, Razavi H, et al. (2011): A systematic review of hepatitis C virus epidemiology in Asia, Australia and Egypt. Liver Int;31 (Suppl 2):61-80.

53. Stasi et al. (2015): Evaluation of the prognostic value of liver stiffness in patients with hepatitis $\mathrm{C}$ virus treated with triple or dual antiviral therapy: Aprospective pilot study. World J Gastroenterol, 21(10): 3013-3019.

54. Thomas, D. L. (2010).Curing hepatitis C with pills-A step toward global control. Lancet; 376, 1441-1442.

55. Thompson AJ, Muir AJ, Sulkowski MS, et al. (2010): Interleukin-28B polymorphism improves viral kinetics and is the strongest pretreatment predictor of sustained virologic response in hepatitis $\mathrm{C}$ virus-1 patients. Gastroenterology; 139: 120-9, e18.

56. Wan L, Kung YJ, Lin YJ, et al. (2009): Th1 and Th2 cytokines are elevated in HCV-infected SVRa patients treated with interferon-alpha. Biochem Biophys Res Commun.; 379:855-60.

57. Yoneda S, Umemura T, Joshita S, Ichijo T, Matsumoto A, et al. (2011): Serum chemokine levels are associated with the outcome of pegylated interferon and ribavirin therapy in patients with chronic Hepatitis C. Hepatol Res 41: 587-593.

58. Zeremski M, Petrovic LM, Chiriboga L, Brown QB, Yee HT, et al. (2008): Intrahepatic levels of CXCR3associated chemokines correlate with liver inflammation and fibrosis in chronic hepatitis C. Hepatology. 48: 1440-1450 doi:10.1002/hep.22500. 